Kolaborasi : Jurnal Administrasi Publik, Desember 2019 Volume 5 Nomor 3

\title{
Formulation of Local Development Policy for Youth In South Tangerang City
}

\author{
Evi Satispi ${ }^{1, *}$, Muhamad Taslim ${ }^{2}$ \\ ${ }^{1,2}$ Program Studi Magister Ilmu Administrasi Publik, Fakultas Ilmu Sosial dan Politik, \\ Universitas Muhammadiyah Jakarta, Indonesia
}

\begin{abstract}
Social problems in youth become a matter that is always considered and reviewed by the government for the development of the personality of these young people. This study aims to analyze the policy formulation of Regional Regulation No. 1 of 2019 concerning Youth Development in South Tangerang. Youth Development Policy Formulation departs from youth issues including unemployment, youth behavior that is at risk of crime, thuggery, and drug abuse, there is no legal umbrella governing youth development in the city of southern Tangerang and youth infrastructure. The method used is descriptive with a qualitative approach. This research uses the theory of the Riant Nugroho formulation stage, while the stages start from policy issues, forming a formulation team, pre-policy process, public process 1, formulation of draft 1, public process 2, formulation of draft 2, special focus, final draft and determination of policy. In the policy formulation stages Riant Nugroho prioritizes the stages in formulating a policy regulation or law. The results showed that the stages in formulating youth development policy formulation by the south tangerang city government had been implemented well so as to produce a youth development policy in south tangerang. Not only the stages of formulation that are of concern from the internal side, youth also experience obstacles such as cross-regional Cooperation Organizations that have not been synchronized in terms of youth development and empowerment programs as well as inadequate infrastructure facilities that encourage youth development and empowerment.
\end{abstract}

Keywords: Public Policy Formulation, Regional Regulation, Youth

\begin{abstract}
Abstrak
Permasalahan sosial pada pemuda menjadi suatu hal yang selalu diperhatikan dan ditinjau akan perkembangan kepribadian para pemuda tersebut oleh pemerintah. Penelitian ini tujuan untuk menganalisis formulasi kebijakan pada Peraturan Daerah Nomor 1 Tahun 2019 Tentang Pembangunan Kepemudaan di Tangerang Selatan. Formulasi Kebijakan Pembangunan Kepemudaan berangkat dari masalah kepemudaan diantaranya masalah pengangguran, perilaku pemuda yang beresiko kepada kriminalitas, premanisme, dan penyalahgunaan narkoba, belum adanya payung hukum yang mengatur tentang pembagunan kepemudaan di kota tangerang selatan ini serta sarana prasarana pemuda. Metode yang digunakan adalah deskriptif dengan pendekatan kualitatif. Dalam Penelitian ini menggunakan teori tahapan formulasi Riant Nugroho adapun tahapannya mulai dari isu kebijakan, membentuk tim perumus, proses pra kebijakan, proses publik ke 1, rumusan draft 1 , proses publik ke 2, rumusan draft 2, FGD khusus, draf final dan penetapan kebijakan. Dalam tahap tahap formulasi kebijakan Riant Nugroho lebih mengedepankan tahapannya dalam memformulasi sebuah kebijakan peraturan atau undang-undang. Hasil penelitian menunjukkan bahwa tahapan tahapan dalam melakukan formulasi kebijakan pembangunan kepemudaan yang dilakukan pemerintah kota tangerang selatan telah diterapkan dengan baik sehingga menghasilkan kebijakan perda pembangunan kepemudaan di Tangerang Selatan. Tidak hanya tahapan formulasi saja yang menjadi perhatian dar sisi internal, kepemudaan juga mengalami kendala seperti kerjasama lintas Organisasi Perangkat Daerah yang belum sinkron dalam hal program
\end{abstract}


Kolaborasi : Jurnal Administrasi Publik, Desember 2019 Volume 5 Nomor 3

pembinaan dan pemberdayaan pemuda serta belum optimalnya sarana prasarana yang mendorong pembinaan dan pemberdayaan kepemudaan.

Kata kunci: Perumusan Kebijakan Publik, Peraturan Daerah, Kepemudaan

${ }^{*}$ Penulis Korespondensi

Email: evi.satispi@umj.ac.id 
Kolaborasi : Jurnal Administrasi Publik, Desember 2019 Volume 5 Nomor 3

\section{INTRODUCTION}

In terms of economic demography, youth are assets to drive development, but on the other hand youth can be a burden, therefore the existence of youth needs to be managed effectively. The Central Statistics Agency states that in 2017 the number of youth in Kota Tangerang Selatan reached 432,608 people or $26.30 \%$ of the total population of $1,644,899$. Reflecting on these data, young people play an important and strategic role in the progress of the City of South Tangerang. Therefore youth development is an inseparable part of regional and national development interests.

Table 1. Total Population of South Tangerang City in 2017

\begin{tabular}{lccc}
\hline \multirow{2}{*}{ Districts } & \multicolumn{3}{c}{ Total Population (Person) } \\
\cline { 2 - 4 } & $\mathbf{2 0 1 5}$ & $\mathbf{2 0 1 6}$ & $\mathbf{2 0 1 7}$ \\
\hline Setu & 80,811 & 83,777 & 86,783 \\
\hline Serpong & 170,731 & 177,677 & 184,761 \\
\hline Pamulang & 332,984 & 341,967 & 350,923 \\
\hline Ciputat & 225,974 & 232,559 & 239,152 \\
\hline $\begin{array}{l}\text { Ciputat } \\
\text { Timur }\end{array}$ & 202,386 & 206,729 & 211,003 \\
\hline $\begin{array}{l}\text { Pondok } \\
\text { Aren }\end{array}$ & 366,568 & 379,354 & 392,284 \\
\hline $\begin{array}{l}\text { Serpong } \\
\text { Utara }\end{array}$ & 163,755 & 171,749 & 179,993 \\
\hline $\begin{array}{l}\text { Kota } \\
\text { Tangerang } \\
\text { Selatan }\end{array}$ & $\mathbf{1 , 5 4 3 , 2 0 9}$ & $\mathbf{1 , 5 9 3 , 8 1 2}$ & $\mathbf{1 , 6 4 4 , 8 9 9}$ \\
\hline
\end{tabular}

The city of South Tangerang is facing a demographic bonus where the South Tangerang area is the buffer zone of the city of Jakarta, namely the abundant availability of labor or productive human resources. Conditions should be supported by the availability of jobs so it does not cause social inequality. According to Keyfitz (1989) Inequality between supply and demand for educated workforce causes graduates at every level to be forced to accept jobs that were previously filled by those with lower education and will ultimately reduce the quality of the well being of the youth themselves.

The high unemployment rate at working age in South Tangerang City, which is $6.13 \%$ of the total workforce should be made a priority problem. The success of youth development, especially in creating quality human resources (HR) and having a competitive advantage should be encouraged by the variety of youth programs and also infrastructure and facilities in order to increase youth resources.

One formula for overcoming this problem is that youth in South Tangerang City are given active participation in development. The youth approach as a subject not only the object of development must be fully implemented in South Tangerang City by referring to the National Development Program (Propenas) 2000-2004 which includes a program to encourage "youth participation" with the aim of: providing greater 
Kolaborasi : Jurnal Administrasi Publik, Desember 2019 Volume 5 Nomor 3

opportunities for young women to strengthen identity and potential by actively participating in development. This program has the following objectives:

1. Increased youth participation in social institutions and youth organizations.

2. The formation of laws and regulations that guarantee the freedom of youth to organize themselves responsibly.

3. Increasing the number of young entrepreneurs.

4. Decreasing the number of cases of drug abuse by youth.

5. Reducing crime rates committed by youth.

In addition to the participatory approach, the youth development and empowerment program is a legal framework that establishes a government agency with clear mandates, authorities and responsibilities in the management and implementation of youth development and empowerment.

Youth in Law No. 40 of 2009 is an Indonesian citizen aged 16 to 30 years who is entering an important period of growth and development. According to the results of the 2017 Susenas, Indonesia is home to 63.36 million youths, which is a quarter of the total population of Indonesia. There are more male youth than female youth, with a sex ratio of 102.36 , which means that for every 102 young men there are 100 female youth. The percentage of youth in urban areas is greater than in rural areas (25.22 percent compared to 23.19 percent). (Indonesian Youth Statistics, in 2017)

In the history of national civilization, youth is a nation asset that is very expensive and priceless. The progress or destruction of the nation and the State depends a lot on its youth as agents of change. At every development and change of civilization there is always a young blood that pioneered it. However, young people in Indonesia today have lost much of their identity, especially in terms of nationalism and patriotism (love of Indonesia's homeland). Therefore, there is a need for rethinking (re-inventing) and re-inventing (rediscovery) in the nation's character building for youth with a nationalist and patriotism insight to rediscover national identity.

In 1928 Indonesian youth shook the world with manifestoheroic by declaring the Youth Pledge. Indonesian youths became pioneers in the process of the rise of the Indonesian nation to carry out systematic resistance to imperialism. In 1998 Indonesian youths 
Kolaborasi : Jurnal Administrasi Publik, Desember 2019 Volume 5 Nomor 3

also carried out a reformation movement towards the New Order government. Towards a reform government. But it is very ironic, because until the twenty-first journey of the reform order, which has been colored by the national leadership with five presidents, we are still not out of the crisis. Unemployment is rampant, there is a threat of national disintegration, widespread corruption, and the nation's morale is destroyed. A big question which is at the same time a big problem for Indonesian youth is "what will happen to the nation and Indonesian youth in the future?"

Youth is the pulse of national life. The presence of the youth's potential and its movements which are loaded with intellectual values and the desire to rise must be able to continue to be developed in such a way as to achieve the dynamic prosperity of the nation and to improve every dimension of its people's lives. Indonesia's change from time to time for the persistence of the youth movement proves that youth are able to play an active role as the front guard in the process of struggle, renewal, and nation building.

Youth has always been the vanguard in every change and national development. The 1998 reforms are evidence that youth and students are at the forefront of overthrowing a regime that is deemed to have deviated from the ideals of the 1945 Constitution and national development. So it is not excessive when we say the word "youth" is always synonymous with idealism, enthusiasm, unyielding, creative, and competitive.

In this research, the writer conducted observation in the library of the University of Muhammadiyah Jakarta and through social media that in writing the title of the thesis there were not many sources or data on the title of the policy formulation so that this became the writing's interest in conducting research in the policy formulation.

Youth is not only placed as the beneficiary of a development, but also must be involved as a controller in the decision making process that will affect the development of Indonesia, a homeland that will be led by young people. For this reason, efforts are needed to ensure youth's dignity in the development planning, implementation and evaluation processes. Regions / provinces must continue to place several youth representatives in the Indonesian development planning process.

One of the obstacles faced is the not yet developing a common view of the problem, which results in differences in understanding of the needs and models 
Kolaborasi : Jurnal Administrasi Publik, Desember 2019 Volume 5 Nomor 3

of treatment. This can be seen from the strategy of handling different problems among DPOs, law enforcement officials, and other stakeholders. Taking into account this, the City of South Tangerang really needs the existence of Regional Regulations that are able to unite the views, synergize all the coping strategies in various institutions, and formulating local regulations on youth.

Based on the background of youth, local regulations and formulations in issuing the local regulation policy, researchers are encouraged to examine the "Formulation of Youth Development Perda Policy in South Tangerang City".

Based on the background description above, the issues that will be examined in this study are as follows: What are the stages of the Formulation of Youth Development Policy in the City of South Tangerang?.

Based on the background and the formulation of the problems that are the focus of research are as follows: To analyze the stages of the formulation of local youth development policy in the city of South Tangerang.

\section{Literature Review}

\section{Theory of Public Policy}

Public policy must be derived in a series of implementation instructions and technical guidelines that apply internally in the bureaucracy. Meanwhile, from the community side, what is important is the existence of a standard of public service that is his right, who can get it, what are the requirements, as well as what form of service. This will bind the government (state) as the service provider and the community as the service recipient. According to Anderson, (Winarno, Budi 2008: 93) said the formulation of policies involves efforts to answer the question of how various alternatives were agreed upon for the problems being developed and who participated Rose in (Agustino, 2014: 7) defines public policy as a long series of many or a few activities that are interconnected and have consequences for the stakeholders as different decisions. Another definition of other public policies was offered by Friedrich in (Agustino, 2014: 7) which says that public policy is a series of actions or activities proposed by a person, group, or government in a particular environment where there are obstacles and possibilities where the policy is proposed to be useful in overcoming it to achieve the intended purpose.

Dye's opinion in (Sulistio, 2013: 2) states that public policy is whatever the government chooses to or does not do, 
Kolaborasi : Jurnal Administrasi Publik, Desember 2019 Volume 5 Nomor 3

the definition implies that public policy concerns choices that must be made or not made by the government.

Anderson in (Agustino, 2014: 7) provides an understanding of the definition of public policy in his book Public Policy Making is a series of activities that have a specific purpose or goal that is followed and implemented by an actor or group of actors associated with a problem or a matter that is needed. This policy concept focuses on what is actually done rather than what is proposed. And this is what distinguishes policy from a decision which is a choice among several alternatives.

Meanwhile, according to Sulistio (2013:

3) public policy is a series of decisions taken and actions taken by public institutions (government agencies or bodies) together with political elite actors in order to resolve public problems in the interests of the whole community . In relation to these definitions, it can be concluded several main characteristics of a definition of public policy (Agustino, 2014: 8).

Based on the understanding of public policy above, it is concluded that the policy is a set of government actions that are regulating in order to respond to problems faced by the community and have specific goals, oriented to the public interest (community) and aiming to overcome problems, meet the desires and demands of all members Public. The policy also contains all the actions of the government both carried out or not carried out by the government which in its implementation there is an element of coercion to the implementers or users of the policy to be obeyed, this is in line with Easton's opinion that the policy contains coercive values that the government can legally carry out as a policy maker.

\section{Policy Formulation Theory}

Public policy making is an important function of a government system. This is because the ability and adequate understanding of policy makers in the policy making process is very important for the realization of public policy determination that is fast, appropriate, and adequate. The ability and understanding of the policy-making procedure must also be balanced with the understanding of public policy makers regarding the authority they have.

In his book Dr. Riant Nugroho entitled Policy Making (2015) said the formulation was to carry out the process of making (formulating) policies in accordance with the plans that had been made ,. 
Kolaborasi : Jurnal Administrasi Publik, Desember 2019 Volume 5 Nomor 3

Tjokroamidjojo in (Islamy, 1997: 24) said that policy formulation is the same as policy formation, a series of alternative selection actions that are carried out continuously and never finished, in this case including making decisions. More about the state (public) policy making process. Meanwhile, according to Anderson in (Winarno, 2014: 93) said the formulation of policies involves efforts to answer the question of how various alternatives were agreed upon for the problems being developed and who participated.

Explained by Andreson, the stages of the policy process begin with a policy agenda where of a number of issues, there are issues that will receive serious attention from public officials and the government will consider what actions or steps are taken to address these issues by identifying and specifying the problem and setting it as a policy agenda the government, then the policy formulation stage, in which at this stage the development of proposed actions that will be taken and acceptable in dealing with the problem, at this stage a number of policy proposals will be produced which will be decided by the government and policy makers.

The next stage is the adoption of policies, this stage is carried out the development of support for certain proposals so that it becomes a policy of legitimacy and endorsed by the government. Then the policy implementation phase where at this stage the policies that have been made and approved are implemented by the government administration engine. The last stage is the evaluation of policies in which the government determines whether the policy is effective or not.

According to Sulistio (2013: 22) policy formulation is the development of policy alternatives in dealing with problems on the public agenda. Policy formulation takes place within government bureaucracy, offices of interest groups, legislative committee rooms, special commission meetings, and policy planning organizations, also known as "think tanks". Thus, the process of policy formulation can be understood as the process of making a public policy. the intended process is the process of transforming inputs into outputs.

\section{Policy Formulation Stage}

To better understand the process of policy formulation, the writer uses the theory of policy formulation stages using Dr. Riant Nugroho who in his book "policy making" (2015: 66-70) suggests that the process of policy formulation in general can be described 
Kolaborasi : Jurnal Administrasi Publik, Desember 2019 Volume 5 Nomor 3

simply in the following sequence of processes:

1. Policy issues. Policy issues from shared life, both at the local, national and global level. Issues of problems can be in the form of problems and or needs of the community and / or countries that are fundamental, have a large scope of coverage, and require government regulation. To capture the policy issue ideally is less than 7 days.

2. Formulation team, After the government has grasped the issue, it is necessary to form a policy formulation team consisting of relevant bureaucratic officials and public policy experts. The time to form this team is at most 7 days.

3. Pre-Policy. The policy formulation team formulated (2a) the policy text, then $(2 b)$ formulated a zero draft policy. The policy text which contains the justification for policy making, which contains the philosophy referred to, namely Pancasila and articles in the 1945 Constitution. While the zero draft is a matter that will be governed by the policy and its consequences. But ideally it has also been arranged in the form of articles. To formulate a joint policy draft and a zero draft ideally 2 work weeks (10 days).

4. Public 1, Once formed, the formulation of the zero draft policy is discussed with public forum 1 , at the following levels :

a. The first public forum, namely policy experts and who is pleased with related issues. If possible, it is necessary to include legislative members in charge of the related fields. This forum discussion is mostly held 3 times in 1 month.

b. After that, a second public forum discussion was held with government agencies outside the government institutions that formulated the policy. These inter-agency meetings should ideally be held 3 times in 1 month.

c. The third public forum discussion is with those who are directly related to policy or who are directly affected. The third public forum discussion involved commissions or related fields in the legislative body. This discussion should ideally be held 3 times in 1 month.

5. Draft Formulation 1. From stage 4 a product is produced in the form of a "draft policy" or "draft law". The text of this draft is in the form of articles which refer to academic texts and the zero draft.

6. Public 2. The draft policy is discussed again with stages that are almost the same as the previous public forum viz

a. The first public forum, namely policy experts and experts relating to related 
Kolaborasi : Jurnal Administrasi Publik, Desember 2019 Volume 5 Nomor 3

issues. The purpose of this discussion is to verify academically. Time in this discussion forum is 3 times a month.

b. The second public forum is with government agencies outside the government institutions that formulated the policy. This meeting between agencies should ideally be held 3 times in 1 month.

c. The third public forum is with parties directly related to policy or directly affected. This discussion should ideally be held 3 times in 1 month. The purpose of this discussion forum is to obtain social and political verification from directly related community groups.

d. The fourth public forum is with all parties widely involved by presenting community leaders. This discussion should ideally be held twice a month. The purpose of this discussion forum is to get input on policies to be made.

7. Formulation of Draft 2. The results of this public discussion will then be used as material for the preparation of the articles of the policy article which will be carried out by the formulating team. This draft is called draft 2 with the formulation period of 1 work week.

8. Special FGD. At this stage the drafting team was accompanied by special policy experts and legal experts to process draft 2 to become the final draft. At this stage a special FGD can be done 1 time.

9. Final Draft. The results of the special FGD forum in the form of a final draft became the final draft to be submitted to the top leaders of the relevant government agencies.

10. Ratification of the policy. The final draft is submitted to the leadership of a government organization that has the authority. The drafting team leader oversees the approval process to ensure there is no "sabotage" or "free rider" on the way to ratification. If the text referred to is a draft law / regulation then the form of ratification from the executive to be submitted to the legislation process. If the policy is within the scope of the executive can be submitted to the policy implementation process, then, as mentioned above the legislative process entered into the stage of legislation.

\section{RESEARCH METHODS}

This research method uses descriptive research with a qualitative approach. The author chose this research because qualitative research is comprehensive, dynamic, and not generalizing. This is in line with the purpose of research in seeing how the stages of formulation of youth development regulations in the city of 
Kolaborasi : Jurnal Administrasi Publik, Desember 2019 Volume 5 Nomor 3

south Tangerang. Data collection techniques used in research are interviews, observation, documentation.

\section{RESULTS AND DISCUSSION}

\section{Phase 1 (Policy Issues)}

Youth Development Policy in the City of South Tangerang is an initiation from the Government of the City of South Tangerang, in this case proposed by the Department of Youth and Sports. Youth Development Policy is separated from youth issues and the hopes of the South Tangerang City Government in future regional development. Riant Nugroho said that policy issues can be in the form of problems and or needs of the community and / or countries that are fundamental, have a large scope of scope, and require government regulation. In the context of youth development policies in the City of South Tangerang, there is a problem, namely where the City of South Tangerang as a city that has reached the age of a decade is facing a demographic bonus, namely the abundant availability of labor or productive human resources. Conditions should be supported by the availability of jobs so it does not cause social inequality. According to Keyfitz (1989) Inequality between supply and demand for educated workforce causes graduates at every level to be forced to accept jobs that were previously filled by those with lower education and will ultimately reduce the quality of the well being of the youth themselves.

The high unemployment rate at working age in South Tangerang City, which is 42,058 or $6.13 \%$ of the total workforce (BPS Kota Tangerang Selatan, 2016) should be made a priority problem. The success of youth development, especially in creating quality human resources (HR) and having a competitive advantage should be encouraged by the variety of youth programs and also infrastructure and facilities in order to increase youth resources.

Table 2. Employment of the City of South Tangerang in 2014, 2015 and 2017

\begin{tabular}{lccc}
\hline \multicolumn{1}{c}{ Description } & \multicolumn{3}{c}{ Total Population (Person) } \\
\cline { 2 - 4 } & $\mathbf{2 0 1 4}$ & $\mathbf{2 0 1 5}$ & $\mathbf{2 0 1 7}$ \\
\hline $\begin{array}{l}\text { Working age } \\
\text { population }\end{array}$ & $1,118,8$ & $1,160,0$ & 242,89 \\
\hline Working force & 705,321 & 685,752 & 708,66 \\
& & & 7 \\
\hline a. Employment & 656,498 & 643,694 & 660,26 \\
& & & 5 \\
\hline \multicolumn{1}{c}{ b. Unemployme } & 48,823 & 42,058 & 48,402 \\
\hline $\begin{array}{l}\text { Not the work force } \\
\text { nt }\end{array}$ & 413,506 & 474,269 & 534,22 \\
\hline $\begin{array}{l}\text { Force participation } \\
\text { rate }\end{array}$ & 63.04 & 59.12 & 57.02 \\
\hline $\begin{array}{l}\text { Open unemployment } \\
\text { rate }\end{array}$ & 6.92 & 6.13 & 6.83 \\
\hline $\begin{array}{l}\text { Job opportunity rate } \\
\text { (\%) }\end{array}$ & 93.08 & 93.87 & 93.17 \\
\hline
\end{tabular}

In addition to the problem of unemployment, youth in South 
Kolaborasi : Jurnal Administrasi Publik, Desember 2019 Volume 5 Nomor 3

Tangerang City are also faced with other problems such as risky behavior (criminality or thuggery) and also drug abuse. This phenomenon certainly has a broad impact not only on the individual youth itself, but also influences the growth and development of Tangerang City itself. To understand the concerns and practices of government and community-related youth, there is a need to apply the notion of "governmentality" to youth governance (Nadesan 2010), and especially to efforts to manage and encourage successful and non-risky "transitions".

Youth development organized by the local government is not only carried out by the Youth and Sports Agency but also the Regional Representative Council. One of the obstacles faced is the not yet developing a common view of the problem, which results in differences in understanding of the needs and models of treatment. This can be seen from the strategies to deal with different problems among DPOs, law enforcement officials, and other stakeholders. Taking this into account, the City of South Tangerang really needs the existence of Regional Regulations that are able to unite the views, and synergize all the coping strategies in various institutions, in the form of regional regulations on youth.
The purpose of establishing youth development policies in order to realize young people who believe and fear God Almighty, noble, healthy, intelligent, creative, innovative, independent, democratic, responsible, as well as having the spirit of leadership, entrepreneurship, and leadership, it is necessary to develop Youth so that youth are able to actively participate in regional and national development and be competitive in various activities at the regional, national and international levels. South Tangerang City as a buffer zone of the capital, which is inhabited by young people from various regions with different backgrounds from education, religion, culture, social and economic strata, the development of Youth in South Tangerang City becomes important both for the City of South Tangerang and the nation and country for the present and the future. The implementation of Youth Development so far has been carried out by various Regional Work Units based on the Mayor's policy, so that youth development programs and activities have not been integrated and sustainable. Therefore, a Regional Regulation on Youth is needed to realize legal certainty for Local Governments, Youth Organizations, and 
Kolaborasi : Jurnal Administrasi Publik, Desember 2019 Volume 5 Nomor 3

the community in organizing Youth in South Tangerang City.

In regional development, young people have the potential and strategic role that they need to develop their potential and role through awareness, empowerment, and development in a unified youth development that is planned, directed, integrated, and sustainable which is part of regional development. The Youth Development Policy which is regulated in this Perda prioritizes the active role of youth, Youth Organizations, the community, and business people who are the main potential resources in Youth development in South Tangerang City. Through youth development, it is expected that young people in South Tangerang City will become young people as the successors of cultural noble values and ideals of the national struggle and resources for regional and national development, Youths who have noble, reliable, tough, smart, independent, and professional qualities, so that able to participate in regional and national development, and able to compete in various activities at national and international levels.

\section{Phase 2 (Policy Formulation Team)}

The policy formulation team consists of relevant bureaucratic officials and public policy experts. Endang said that the formulating team in the formation of this Youth Development Regulation was the Legal Field of the Mayor, in this case the Mayor's Expert, Mr. Safrudin and was assisted by a Team from the Department of Youth and Sports. Not only that, based on the information conveyed by Sugeng Sutanto, he said that, he also participated in drafting the Regional Regulation on Youth Development. The drafting team is an expert in the field of law in this case legal drafting. Even so Sugeng Sutanto is a Masters in Public Policy, so that the policy formulation team is a competent team.

Table 3. List of Participants in the Policy Formulation Team

\begin{tabular}{llllll}
\hline Team Pansus & & \multicolumn{2}{l}{ Team Pemerintah } & \multicolumn{2}{l}{ Team Ahli } \\
\hline Name & Position & Name & Position & Name & Position \\
\hline Syawqi & Ketua & Wiwi & Kadis & $\begin{array}{l}\text { Dr. } \\
\text { Sugeng }\end{array}$ & Tenaga \\
& & & & Ahli/Pakar \\
& & & & Sutanto & \\
\hline Siti & Sekretaris & Endang & Kabid & & \\
Chodijah & & & Pemberdayaan & \\
& & & Pengembangan & \\
\end{tabular}


Kolaborasi : Jurnal Administrasi Publik, Desember 2019 Volume 5 Nomor 3

\begin{tabular}{|c|c|c|c|}
\hline & & & Pemuda \\
\hline Baihaqi & Anggota & Tati & Kasie Pemuda \\
\hline Safira & Anggota & Syarif & $\begin{array}{l}\text { Kasie } \\
\text { Pemberdayaan }\end{array}$ \\
\hline Eeng & Anggota & Marsudin & $\begin{array}{l}\text { Kasie } \\
\text { Pengembangan }\end{array}$ \\
\hline $\begin{array}{l}\text { Hadi } \\
\text { Wibawa }\end{array}$ & Anggota & Syafrudin & TA Walikota \\
\hline Edi Mamat & Anggota & & \\
\hline Choir & Anggota & & \\
\hline Bambang & Anggota & & \\
\hline
\end{tabular}

\section{Phase 3 (Pre-Policy Process)}

Behind the problems of youth there is the potential of the younger generation, namely: First, Idealism and critical power. Sociologically the younger generation is not well established in the existing order, so that he can see the flaws in the order naturally and be able to find new ideas. Idealism and the existence of creativity need to be equipped with a balanced sense of responsibility. Second, dynamics and creativity. The existence of idealism in the younger generation, causing them to have the potential for dynamism and creativity, namely the ability and willingness to make changes, renewal and refinement of existing deficiencies or to put forward new ideas. Third, the attitude of independence and pure discipline (self discipline). The young generation has a desire to always be independent in their attitudes and actions. Which independence needs to be complemented by pure discipline of awareness in themselves, so that they can realize reasonable limits and have tolerance.

South Tangerang City as a buffer of the Capital, which is inhabited by young people from various regions with diverse backgrounds from education, religion, culture, social and economic strata, then youth development in South Tangerang City becomes important both for the City of South Tangerang and the nation and state for the present and future. The implementation of youth development has been carried out by various Regional Apparatus Organizations (OPD), so that youth development programs and activities have not been integrated and sustainable. Therefore, a Regional 
Kolaborasi : Jurnal Administrasi Publik, Desember 2019 Volume 5 Nomor 3

Regulation on Youth is needed to realize legal certainty for Local Governments, Youth Organizations, and the community in organizing youth in South Tangerang City.

The implementation of youth development regulated in the Regional Regulation prioritizes the active role of youth, youth organizations, communities, and business actors who are the main potential resources in youth development in South Tangerang City. Through youth development, it is expected that young people in South Tangerang will become young people as the successors of the noble values of culture and the ideals of the national struggle and resources for regional and national development, young people who have noble, reliable, resilient, intelligent, independent, and professional, so that they are able participate in regional and national development, and be able to compete in various activities at the national and international levels.

Second, Juridical Basis, This juridical study is intended to see the legislation that becomes the legal instrument as a basis in the formation of a Regional Regulation on Youth. By taking into account these laws and regulations, it is hoped that the draft of this regional regulation will not conflict with other laws and regulations which are equal in harmony with other laws and regulations which can be applicable and solutive to social welfare problems.

\section{Phase 4 (First Public Process)}

Once formed, the formulation of the zero draft policy is discussed with public forums. In the public process there are forums that must be carried out as a forum for the public, especially for beneficiary communities and the WTO to be involved in the implementation of youth development policies.

In the public process in the discussion of youth development policy does not carry out a special expert forum, but the forums that are held are a joint forum between experts, OPD, DPRD, youth groups consisting of OKP, Student Organizations, and Student Organizations.

Then the forum carried out later was a government forum held in the DPRD when a joint discussion was held. In this government forum experts and the Ministry of Justice and Human Rights of the Banten Representative Office were also involved. Sugeng said "the involvement of the Ministry of Justice and Human Rights of the Banten Representative Office is a pilot project in the formation of regional regulations". The expert was involved in 
Kolaborasi : Jurnal Administrasi Publik, Desember 2019 Volume 5 Nomor 3

the public process five times, four times with the government and once in the DPRD.

Furthermore, the beneficiary Forum was held in the form of socializing Regional Regulations and at the same time gathering input from youth organizations. Dissemination to Student Organizations (OSIS) and Student Organizations (Student Executive Bodies) is carried out separately with other Youth Organizations such as
KNPI, Youth Organization, and the like. Then the public forum is held as a joint forum between experts, government, beneficiaries, and also youth leaders from Betawi.

The discussion in each of the forums is a Draft Regulation consisting of 13 Chapters and 57 articles, each Chapter contains about (the draft document attached in the annex): The draft 0 in the pre-policy process is as follows:

Table 4. Draft Regulation consisting

\begin{tabular}{clc}
\hline Chapter & Remark & Number of Articles \\
\hline I & General requirements & 1 \\
\hline II & $\begin{array}{l}\text { Duties, authorities and responsibilities of local } \\
\text { governments }\end{array}$ & 3 \\
\hline III & Roles, Responsibilities and rights of youth & 3 \\
\hline IV & Planning & 1 \\
\hline V & Youth Development & 26 \\
\hline VI & Infrastructure and facilities & 5 \\
\hline VII & Youth organization and task force & 5 \\
\hline VIII & Recording and data information & 4 \\
\hline IX & Appreciation & 1 \\
\hline X & Youth Partnership & 3 \\
\hline XI & Guidance and supervision & 2 \\
\hline XII & Funding & 1 \\
\hline XIII & Closing & 2 \\
\hline & Total of Articles & $\mathbf{5 7}$ \\
\hline
\end{tabular}

\section{Phase 5 (Formulation 1)}

From the results of the discussion of academic texts and draft 0 will be discussed in the public process forum to generate input from expert groups, governments and beneficiaries. The government from the elements of OPD who participated in the implementation of local regulations on youth development. The Draft of Youth
Development Delegation to the Mayor Regulations as many as 10 Articles, namely:

a. Article 8 Paragraph (4) Further provisions regarding the Regional action plan as referred to in paragraph (3) letter e are regulated by the Mayor Regulation

b. Article 11 Paragraph (3) Further provisions regarding Youth Awareness 
Kolaborasi : Jurnal Administrasi Publik, Desember 2019 Volume 5 Nomor 3

as referred to in paragraph (1) and paragraph (2), are regulated by the Mayor Regulation.

c. Article 13 Paragraph (3) Further provisions regarding Youth Empowerment as referred to in paragraph (1) and paragraph (2), are regulated by the Regulations of the Mayor.

d. Article 26 Further provisions regarding the Development of Youth Leadership as referred to in Article 15 through Article 25, are regulated by the Mayor Regulation. Article 32 Further provisions regarding Youth Entrepreneurship Development as referred to in Article 27 through Article 31 are regulated by the Mayor Regulation.

e. Article 34 Further provisions regarding the Development of Youth Leadership as referred to in Article 33, are regulated by the Mayor Regulation. Article 39 Further provisions regarding the management of Youth Infrastructure and Facilities as referred to in Article 38 shall be regulated by the Mayor Regulation.

f. Article 43 Further provisions regarding Youth Organization as referred to in Article 40 to Article 42, are regulated by the Mayor Regulation.

g. Article 44 Further provisions regarding the Youth task force as referred to in paragraph (1), are regulated by the Mayor Regulation.

Article 49 Further provisions regarding the Award referred to in paragraph (1), paragraph (2) and paragraph (3) are regulated by the Mayor Regulation.

In the discussion of the Draft Regional Regulation all sub-groups agreed on the contents of the Draft Regional Regulation to be ratified as a Regional Regulation.

\section{Phase 6 (Second Public Process)}

At the second stage of the public process, the draft is discussed again at a stage that is almost the same as the first public process. However, the implementation of the second public process was carried out by the Special Committee (Pansus) of South Tangerang City DPRD. The second stage of the public process involves the DPRD Special Committee, the Department of Youth and Sports and OPD who will be involved in the implementation of the Youth Regulation, the beneficiaries in this case are represented by the KNPI, and experts.

In the discussion of the public process there are inputs as follows: First, the change in nomenclature of the perda title from the beginning of youth then changed to youth organization. The youth title is the title submitted by the 
Kolaborasi : Jurnal Administrasi Publik, Desember 2019 Volume 5 Nomor 3

Dispora to the Regional Regulation Forming Board (Bapemperda). Baihaqi, a member of the special committee, suggested that the title be changed to youth development, because it was an appropriate title. According to him, if the title is youth, it has been regulated in Law Number 40 of 2009 concerning youth. The regional regulation being discussed is in the context of providing a basis and legal certainty to the organization in the context of the implementation of its youth which will be discussed later in accordance with the Title. Hasyim who is a team from Dispora said that the discussion on this nomenclature was dynamic and long. According to him, because the rules of the game, if the legislature had changed, the title change had to be agreed upon. Then in the decision making, the special committee agreed to change the title into youth organization. Secondly, there are proposals for additional, regional action plans. Because implementation is a cross-regional OPD work, it is necessary to make a regional action plan in which all related OPDs have their respective roles in youth development. The proposal was accepted and it was agreed that there would be a regional action plan. Third, the proposal for the preparation of the regeneration process in various fields. Whether it's sports, youth organizations, social, politics and other fields. The proposal was accepted and agreed upon. In addition to the three discussions, there are other editorial interpretations and adjustments to the formulation of legislation.

\section{Phase 7 (Formulation 2)}

In the draft stage 2 , the results of the public discussion in the second public process serve as material for the formulation of policy articles that will be carried out by the drafting team.

\section{Phase 8 (Special FGD)}

At this stage the drafting team was accompanied by policy specialists and legal experts to process draft 2 to become the final draft, this process was called the facilitation process. Where Regional Regulations that have been jointly approved are then submitted to the Legal Section of Banten Province for examination and recording of Regional Regulations. After getting an improvement from the Legal Section of the Province of Banten there was a change in the title of the Perda from what was originally the implementation of Youth to Youth Development. Then there was an article that was deleted because it was considered as a repetition, namely in article 11 paragraph 1 points $\mathrm{i}, \mathrm{j}$, and $\mathrm{k}$. the paragraph is considered a repetition of article 11 paragraph 2 which contains: i) 
Kolaborasi : Jurnal Administrasi Publik, Desember 2019 Volume 5 Nomor 3

protection of youth from the dangers of drugs and promiscuity; j) protection of youth from HIV and Aqcuired Immono Deficiency Syndrome, and k) protection of youth from violence and radicalism. Then article 31 contains additional articles from the original one article. As for the contents as follows, article 31 paragraph 1, the Regional Government organizes or facilitates the implementation of Youth entrepreneurship through capital access assistance as referred to in article 27 paragraph (2) letter g. paragraph 2, reads: Capital access assistance as referred to in paragraph (1) aims at providing ease of obtaining business capital.

\section{Phase 9 (Final Draft)}

The results of the special FGD forum in the form of a final draft became the final draft to be submitted to the top leaders of the relevant government agencies. The results of the final draft finally consisted of 13 Chapters and 56 articles from the Draft Regional Regulation which were previously 13 chapters and 57 articles.

\section{Phase 10 (Policy Approval)}

This Regional Regulation was ratified by the DPRD together with the Mayor in December 2018. Then it was determined by the Mayor to become
Regional Regulation No. 1 of 2019 concerning Youth Development in the regional gazette on January 31, 2019 with the registration number of the Regional Regulation of South Tangerang City, Banten: (1/4 / 2019).

\section{CONCLUSION}

Based on the research conducted by the author of the stages of the Formulation of Youth Development Policy in the city of South Tangerang, it can be concluded that the stages of the Formulation of Youth Development Policy in the city of south tangerang run in accordance with the theory of the stages of formulation where the stages that are carried out are policy issues, pre-formulation team, pre-policy, the first public forum, the formulation of draft 1 , the second public forum, the formulation of draft 2, FGD, the final draft to the endorsement stage.

From the background of youth issues in this study, including unemployment issues, youth behaviors that are at risk of crime, thuggery, and drug abuse, the unavailability of facilities and infrastructures, then in the stages of the formulation of youth development local regulation policies have been accommodated in the articles and chapters in the development regulations youth. 
Kolaborasi : Jurnal Administrasi Publik, Desember 2019 Volume 5 Nomor 3

The handling of the unemployment problem is contained in chapter V of Youth Development section four Development of Paragraph 2 Entrepreneurial Development as outlined in articles 27 to 32 , the handling of problems with youth behavior that is at risk of crime, thuggery and drug abuse is regulated in chapter V of Youth Development section one of Article Article 9 paragraph 2 which states youth services as referred to in paragraph (1) is carried out through: (a) Awareness, (b) Empowerment and (c) Development. Whereas the background to the problem of infrastructure sector is contained in chapter VI Infrastructure and Facilities are regulated in articles 35 to article 39 which consists of part one concerning general matters, part two concerning supply and part three concerning management

After the phalcitation stage is completed, the South Tangerang city government will ratify it on January 31 , 2019 under the name PERDA No.1 2019 Youth Development in South Tangerang City.

\section{REFERENCES}

Agustino, Leo, 2014. Dasar-Dasar Kebijakan Publik, Alfabeta, Bandung.
Anderson, James. 1969. Public Policy Making. New York : Holt, Renehart, and Winston

Arikanto, Suharsimi, Prosedur penelitian suatu Pendekatan Praktek, (Jakarta: Renika Cipta, 1996),

Dunn, William N. 2003, Pengantar Analisis Kebijakan Publik, Gadjah Mada Universty Press, Yogyakarta.

Eyestone, Robert. 1971. The Threads of Policy : A Study in Policy Leadership. Indianapolis :BobsMerril

Islamy, M.Irfan, 1997. Prinsip-Prinsip Perumusan Kebijaksanaan Negara, Sinar Grafika, Jakarta.

Jones, Charles O. 1984. An Introduction to The Study of Public Policy. Monterey : Books /Cole Publishing Company

Lindblom, Charles E. 1986. Proses Penetapan Kebijaksanaan. Jakarta: Penerbit Erlangga.

Moleong, Lexy J. 2011. Metode Penelitian Kualitatif, PT. Remaja Rosdakarya, Bandung.

Nugroho, Riant, 2015. Policy Making, Elex Media Komputindo, Jakarta.

Parsons, Wayne.2011. Public Policy: Pengantar dan Praktik Analisis Kebijakan. Jakarta: Penerbit Kencana

Prasetyo, Bambang dan Lina Miftahul Jannah. 2006. Metode Penelitian Kuantitatif : Teori dan Aplikasi. Jakarta : PT Raja Grafindo Persada

Subarsono, 2011. Analisis Kebijakan Publik, Pustaka Pelajar, Yogyakarta.

Sugiyono, 2011. Metode Penelitian Kuantitatif Kualitatif dan $R \& D$, Alfabeta, Bandung

Sulistio, Eko Budi, 2013. Kebijakan Publik (Public Policy),

Theodoulou, Stella Z dan Chris Kofinis. 2004. The Art of the Game: Understanding American Public Policy Making. Belmont, CA: Wadsworth

Thoha,Miftah.2010. Ilmu Administrasi Publik Kontemporer. Jakarta: Kencana Prenada Media Group

Tjokroamidjojo,Bintoro,1976. Analisa Kebijaksanaan Dalam Proses
Perencanaan Pembangunan
Nasional, Majalah Administrator,

Tresiana, Novita, 2013. Metode Penelitian Kualitatif, Bandar Lampung: 
Kolaborasi : Jurnal Administrasi Publik, Desember 2019 Volume 5 Nomor 3

Lembaga Penelitian Universitas Lampung

Wahab, Solichin Abdul, 1990. Analisis Kebijaksanaan Negara, Rineka Cipta, Jakarta.

Widodo, Joko, 2001. Implementasi Kebijakan, Pustaka Pelajar. Bandung. Wijayanti,

Winarno, Budi, 2014. Kebijakan Publik Teori, Proses dan Studi Kasus, Cetakan Kedua, CAPS, Yogyakarta.

Young, Eoin dan Lisa Quinn (2002). Writing Effective Public Policy Paper: a Guide of Edvisers in Central and Eastern Europe. Budapest: Local Government and Public Service Reform Initiative

Arviantoni Sadri, 2009. Model Strategy Pemberdayaan Pemuda Jalanan, Tesis, Jakarta

Astatia Damaiska, 2012, Pemberdayaan Organisasi Pemuda Nasional di DKI Jakarta Oleh Kemenpora Paska Terbitnya Undang Undang Kepemudaan Tahun 2009, Skripsi, Jakarta

Buang Sabdo Waryoko, 2009. Strategy Pemberdayaan Pemuda Indonesia, Tesis, Jakarta

Pipit Widiatmaka, Agus Pramusinto, Kodiran, 2016, Peran Organisasi Kepemudaan Dalam Membangun Karakter Pemuda dan Implikasinya Terhadap Ketahanan Pribadi Pemuda, Jurnal Ketahanan Nasional, Vol.22, No.2, Agustus 2016;180-198

Silvany Yohana, 2012 Analisis Formulasi Peraturan Daerah (PERDA) Kota Depok No.10 Tahun 2011 Tentang Pendirian Perusahaan Air Minum Daerah (PDAM) Kota Depok

Sylvia Yolanda, 2016, Formulasi Kebijakan Penetapan Upah Minimum Propinsi Lampung, Skripsi, Lampung
Antik Bintari, Landrikus Hartarto Sampe Pandiangan, 2016 formulasi kebijakan pemerintah tentang pembentukan badan usaha milik daerah (bumd) perseroan terbatas (pt) mass rapid transit (mrt) jakarta di provinsi dki jakarta, Jurnal Ilmu Pemerintah, ISSN 2442-5958, EISSN 2540-8674

Inggar Saputra, 2017, Peran Organisasi Kepemudaan Dalam Meningkatkan Pemahaman Wawasan Nusantara Di Kalangan Pemuda Indonesia,E- ISSN 2579-9924, ISSN 2579-9878

http://tangselpos.co.id/2018/07/02/pemudadukung-lahirnya-perda-kepemudaan/ diakses pada 02/07/2019

http://www.banteninfo.com/polemikdibalik-kota-tangerang-selatansebagai-kota-layak-pemuda/ diakses pada $02 / 07 / 2019$

https://beritatangsel.com/2018/03/28/libatka n-organisasi-pemuda-disporatangsel-bahas-raperda-kepemudaan/ diakses pada 02/07/2019

https://tangselkota.bps.go.id/ diakses pada $\underline{02 / 07 / 2019}$ 